\title{
Lipophilic Caffeic and Ferulic Acid Derivatives Presenting Cytotoxicity against Human Breast Cancer Cells
}

Teresa L. Serafim, ${ }^{\dagger}$ Filipa S. Carvalho, ${ }^{\dagger}$ Maria P. M. Marques, ${ }^{\ddagger}, \S$ Rita Calheiros, ${ }^{\ddagger}$ Tiago Silva, ${ }_{\nabla}^{\perp}$ Jorge Garrido, ${ }^{\| \perp}$ Nuno Milhazes, ${ }^{\perp, \#}$ Fernanda Borges, ${ }^{\perp}$ Fernanda Roleira, ${ }^{\nabla}$ Elisiário T. Silva, ${ }^{\nabla}$ Jon Holy, and Paulo J. Oliveira, ${ }^{*+}$

${ }^{+} \mathrm{CNC}$, Centre for Neuroscience and Cellular Biology, University of Coimbra, Portugal

${ }^{\ddagger}$ QFM, Research Unit “Molecular Physical-Chemistry”, University of Coimbra, Portugal

${ }^{\S}$ Department of Life Sciences, Faculty of Science and Technology, University of Coimbra, Portugal

"Department of Chemical Engineering, Superior Institute of Engineering of Porto, Portugal

${ }^{\perp}$ CIQUP, Department of Chemistry and Biochemistry, Faculty of Sciences, University of Porto, Portugal

${ }^{\#}$ Health Sciences Superior Institute-North, Gandra PRD, Portugal

${ }^{\nabla}$ CEF-Pharmaceutical Chemistry Group, Faculty of Pharmacy, University of Coimbra, Portugal

${ }^{\circ}$ Department of Anatomy and Cell Biology, University of Minnesota Medical School, Duluth, Minnesota, United States

Supporting Information

ABSTRACT: In the present work, lipophilic caffeic and ferulic acid derivatives were synthesized, and their cytotoxicity on cultured breast cancer cells was compared. A total of six compounds were initially evaluated: caffeic acid (CA), hexyl caffeate (HC), caffeoylhexylamide (HCA), ferulic acid (FA), hexyl ferulate (HF), and feruloylhexylamide (HFA). Cell proliferation, cell cycle progression, and apoptotic signaling were investigated in three human breast cancer cell lines, including estrogen-sensitive (MCF-7) and insensitive (MDA-MB-231 and HS578T). Furthermore, direct mitochondrial effects of parent and modified compounds were investigated by using isolated liver mitochondria. The results indicated that although the parent compounds presented no cytotoxicity, the new compounds inhibited cell proliferation and induced cell cycle alterations and cell death, with a predominant effect on MCF-7 cells. Interestingly, cell cyle data indicates that effects on nontumor BJ fibroblasts were predominantly cytostatic and not cytotoxic. The parent compounds and derivatives

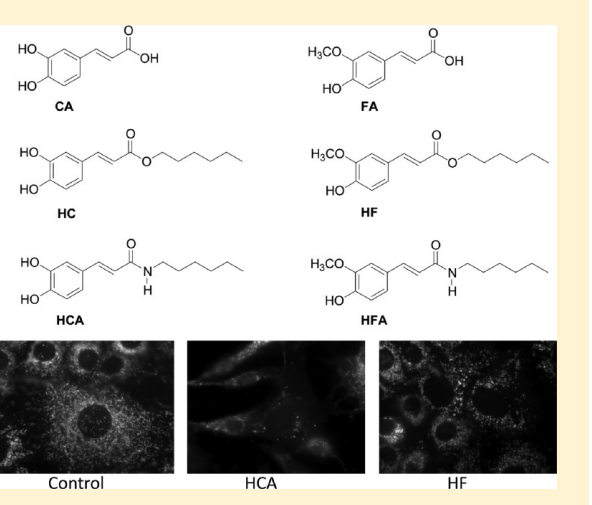
also promoted direct alterations on hepatic mitochondrial bioenergetics, although the most unexpected and never before reported one was that FA induces the mitochondrial permeability transition. The results show that the new caffeic and ferulic acid lipophilic derivatives show increased cytotoxicity toward human breast cancer cell lines, although the magnitude and type of effects appear to be dependent on the cell type. Mitochondrial data had no direct correspondence with effects on intact cells suggesting that this organelle may not be a critical component of the cellular effects observed. The data provide a rational approach to the design of effective cytotoxic lipophilic hydroxycinnamic derivatives that in the future could be profitably applied for chemopreventive and/or chemotherapeutic purposes.

\section{INTRODUCTION}

Diet-associated phenolic compounds, including hydroxycinnamic and hydroxybenzoic acids, are often described as potential antioxidants and consequently inhibitors of deleterious oxidative processes related with cardiovascular and inflammatory diseases and cancer. ${ }^{1-5}$ A large body of scientific evidence suggests that phenolic compounds can act as chemopreventive and/or chemotherapeutic agents. ${ }^{1-4,6-8}$ Specifically, hydroxycinnamic acids and derivatives are known to display relevant antioxidant properties as well as biological activity toward several tumor cells, with their growth-inhibitory potency being strongly dependent on their structural characteristics. ${ }^{9-12}$ For example, it has been demonstrated that caffeic acid phenethyl (CAPE) and benzyl/ alkyl esters display selective antiproliferative activity against some types of cancer cells. ${ }^{1-4,6,7}$ It is also recognized that hydroxycinnamic acids and derivatives can inhibit key proteins in signal transduction pathways (such as MAP-kinases or AP-1) or pathways downstream from the transcription factor NF-kB and modulate cell-cycle regulation and apoptosis. ${ }^{1,8}$

Despite all the interesting biological effects of hydroxycinnamic acids and despite being dietary components, their

Received: March 22, 2011

Published: April 19, 2011 
<smiles>O=C(O)/C=C/c1ccc(O)c(O)c1</smiles>

CA<smiles>CCCCCCOC(=O)/C=C/c1ccc(O)c(O)c1</smiles><smiles>CCCCCCNC(=O)/C=C/c1ccc(O)c(O)c1</smiles><smiles>COc1cc(/C=C/C(=O)O)ccc1O</smiles><smiles>CCCCCCOC(=O)/C=C/c1ccc(O)c(OC)c1</smiles><smiles>CCCCCCNC(=O)/C=C/c1ccc(O)c(OC)c1</smiles>

Figure 1. Chemical structure of hydoxycinnamic parent compounds and derivatives: caffeic acid (CA), hexyl caffeate (HC), and caffeoylhexylamide (HCA); ferulic acid (FA), hexyl ferulate (HF), and feruloylhexylamide (HFA).

bioavailability presents some limitations: although working well in aqueous media, their hydrophilic nature is usually a restriction for lipophilic system protection. ${ }^{13,14}$ In order to develop new and more effective phenolic agents suitable for chemopreventive and/or chemotherapeutic purposes, caffeic and ferulic acid ester and amide derivatives with increased lipophilicity conferred by an additional alkyl chain (Figure 1) were screened in terms of cytotoxicity on three different human breast cancer cell lines, namely, MCF-7, HS578T, and MDA-MB-231, and on a nontransformed human fibroblast cell line (BJ), which was used as a nontumor cell control. The parent compounds, caffeic and ferulic acids, were also used for comparative purposes. The study was accomplished by investigating proliferation, cell cycle, and cell death effects of the test compounds. It is important to note that the antioxidant properties and partition coefficients of the compounds under study were previously assessed. ${ }^{15}$

Among several possible mechanisms for tumor cell cytotoxicity caused by phenolic acids, direct effects on mitochondria can also be envisioned. Mitochondria are involved in several energy and metabolically linked processes, in the generation of reactive oxygen species (ROS), and in several disease-initiated processes; ${ }^{16}$ in fact, the role of mitochondria in carcionogenesis ${ }^{17}$ and anticancer therapy ${ }^{18}$ has also been explored in detail, with this organelle being considered an attractive target of different chemotherapeutics with the ultimate objective of eliminating cancer cells. ${ }^{19}$ In order to investigate whether the test compounds could directly impact mitochondrial physiology and cause a pro-apoptotic increase in membrane permeability, isolated liver mitochondria were incubated with the test compounds. Isolated mitochondrial fractions have been used as a biological model by pharmaceutical companies as a sensitive and reliable biosensor for drug-induced toxicity. ${ }^{20}$

\section{MATERIALS AND METHODS}

Chemicals. Caffeic and ferulic acids, sulforhodamine B, Bradford reagent, and inorganic salts were obtained from Sigma-Aldrich Chemical Co.. Dulbecco's modified Eagle's medium (DMEM), fetal bovine serum (FBS), and penicillin-streptomycin $100 \times$ solution were acquired from GIBCO (New York, NY, USA) and PVDF membranes and Laemmli buffer from BioRad (Hercules, CA, USA). For Western blotting, the primary antibodies used were mouse anti-Caspase-8 (1C12), rabbit anti-p53 (7F5), rabbit anti-Bcl-xl (54H6), anti-Bax (Human Specific), and rabbit anti-Caspase-9 (Human Specific), all from Cell Signaling (Beverly, MA, USA), and mouse anti- $\beta$-Actin (A5441) was from Sigma (Saint Louis, MO, USA). The secondaries antibodies used were goat antirabbit IgG-AP (sc-2007) and goat antimouse IgG-AP (sc-2008), both from Santa Cruz Biotechnology (San Diego, CA, USA). Fluorescent probes tetramethyl rhodaminemethylester (TMRM) and Hoechst 33342 were obtained from Invitrogen (Barcelona, Spain). All reagents and chemical compounds used were of the greatest degree of purity commercially available. In the preparation of every solution, ultrapure distilled water (conductivity $<18 \mu \mathrm{S} \cdot \mathrm{cm}^{-1}$ ), filtered by the Milli Q from a Millipore system, was always used in order to minimize as much as possible contamination with metal ions.

Animals. Male Wistar-Han rats (10 weeks old) were housed in our accredited animal colony (Laboratory Research Center, Faculty of Medicine, University of Coimbra). Animals were group-housed in type III-H cages (Tecniplast, Italy) and maintained in specific environmental requirements $\left(22^{\circ} \mathrm{C}, 45-65 \%\right.$ humidity, $15-20$ changes/h ventilation, $12 \mathrm{~h}$ artificial light/dark cycle, and noise level $<55 \mathrm{~dB}$ ) with free access to standard rodent food (4RF21 GLP certificate, Mucedola, Italy) and acidified water (at pH 2.6 with $\mathrm{HCl}$ to avoid bacterial contamination). This research procedure was carried out in accordance with European Requirements for Vertebrate Animal Research and according to the ethical standards for animal manipulation at the Center for Neuroscience and Cell Biology.

Synthesis and Characterization of the Compounds. The phenolic cinnamic derivatives (Figure 1) were synthesized and identified by both NMR and EI-MS as described previously. ${ }^{15}$ The structural preferences of the phenolic derivatives under study were also determined by vibrational (Raman) spectroscopy (Figure S1, Supporting Information).

Composition of Solutions. All studied compounds were soluble in ethanol, in the concentration range $1.0 \times 10^{-5} \mathrm{~mol} \cdot \mathrm{dm}^{-3}$ to $1.0 \times$ $10^{-4} \mathrm{~mol} \cdot \mathrm{dm}^{-3}$. Phosphate buffered saline solution (PBS): $132.0 \times$ $10^{-3} \mathrm{~mol} \cdot \mathrm{dm}^{-3} \mathrm{NaCl}, 4.0 \times 10^{-3} \mathrm{~mol} \cdot \mathrm{dm}^{-3} \mathrm{KCl} ; 1.2 \times 10^{-3}$ $\mathrm{mol} \cdot \mathrm{dm}^{-3} \mathrm{NaH}_{2} \mathrm{PO}_{4}$. (PBS-T): PBS with $0.1 \%$ Tween; $1.4 \times 10^{-3}$ $\mathrm{mol} \cdot \mathrm{dm}^{-3} \mathrm{MgCl}_{2} ; 6.0 \times 10^{-3} \mathrm{~mol} \cdot \mathrm{dm}^{-3}$ glucose; $1.0 \times 10^{-2}$ $\mathrm{mol} \cdot \mathrm{dm}^{-3}$ HEPES (N-[2-hydroxy-ethyl]piperazine- $N$-[4-butanesulfonic acid]). Trypan blue was used as a $0.04 \%(\mathrm{w} / \mathrm{v})$ solution in PBS.

Cell Culture. MDA-MB-231 (ECACC, United Kingdom), MCF-7 (ECACC, United Kingdom), and HS578T (ATCC, Manassas, VA, USA) breast cancer cell lines, as well as BJ normal fibroblasts (ATCC, Manassas, VA, USA), were cultured in monolayers at $37^{\circ} \mathrm{C}$ in DMEM 
medium with $10 \%$ FBS and $1 \%$ of antibiotic penicillin-streptomycin, in an atmosphere of $5 \% \mathrm{CO}_{2}$. BJ fibroblasts were only used between passage 10 and 25 .

Cell Proliferation Measurement. Cell proliferation assays were conducted in order to evaluate the effect of the test phenolic compounds on tumor and nontumor cell lines, following the protocol described previously by our laboratory: ${ }^{21}$ the test compounds $(1.5 \mu \mathrm{L})$ were added to each well (final volume $500 \mu \mathrm{L}$ ) one day after seeding $1 \times 10^{4}$ cells/ $\mathrm{mL}$ in 48-well plates. Ethanol vehicle controls were also performed. Cells were harvested and analyzed for 1, 3, and 7 days. Cell density was determined by the sulforhodamine B (SRB) assay. After SRB labeling, absorbance was measured in a spectrophotometer at $540 \mathrm{~nm}$. The amount of released dye is proportional to the number of cells present in the sample and is a reliable indicator of cell proliferation. ${ }^{22}$ Results are expressed as a percentage of the control (nontreated) cells, taken as $100 \%$, to equalize for different growth rates between cell lines. All experiments were performed in quadruplicate.

Cell Cycle Analysis. Cell cycle progression was analyzed by using flow cytometry. ${ }^{23}$ All cell lines were incubated with a single concentration $(75 \mu \mathrm{M})$ of the test compounds for 48 and $96 \mathrm{~h}$. Adherent and floating cells were then collected and fixed with cold $70 \%$ ethanol and stored overnight at $-20^{\circ} \mathrm{C}$. After washing and ressuspending in PBS-T, samples were incubated at $37{ }^{\circ} \mathrm{C}$ in $0.5 \mathrm{~mL}$ PBS-T with $20 \mu \mathrm{g} / \mathrm{mL}$ RNase for $45 \mathrm{~min}$, and with propidium iodide at $37^{\circ} \mathrm{C}$, for a further period of $30 \mathrm{~min}$. The percentage of cells in the different cell cycle phases was quantified in a flow cytometer (Becton-Dickenson FACScalibur), using Modfit LT software (Verity Software House, Topsham, ME, USA).

Vital Epifluorescence Imaging of MCF-7 and BJ Cell Lines. Cells were seeded in 6-well plates with a glass coverslip per well, at a density of 5-10 $\times 10^{4}$ and allowed to attach for $24 \mathrm{~h}$. Cells were then treated with either the phenolic solutions or the vehicle (ethanol) for the desired time. Thirty minutes prior the end of the exposure time, the cultures were incubated with TMRM $(100 \mathrm{nM})$ in a PBS solution supplemented with $10 \%$ FBS. In some assays, cells were labeled with Hoechst 33342, $1 \mu \mathrm{g} / \mathrm{mL}$, in order to label nuclei and detect apoptotic chromatin condensation. The images were obtained using a Nikon Eclipse TE2000U epifluorescence microscope.

Western Blotting Analysis. For Western blot analyses, adherent and floating cells were collected after 48 and $96 \mathrm{~h}$ of treatment and were ressuspended in collecting buffer $(20 \mathrm{mM}$ HEPES/NaOH, $\mathrm{pH} 7.5$, $250 \mathrm{mM}$ sucrose, $10 \mathrm{mM} \mathrm{KCl}, 2 \mathrm{mM} \mathrm{MgCl}_{2}$, and $1 \mathrm{mM}$ EDTA) supplemented with $2 \mathrm{mM}$ dithiothreitol (DTT), $100 \mu \mathrm{M}$ phenylmethylsulfonyl fluoride (PMSF), and a protease inhibitor cocktail (containing $1 \mu \mathrm{g} / \mathrm{mL}$ of leupeptin, antipain, chymostatin, and pepstatin A). The cells were then ruptured by carrying out 30 passages through a 27 -gauge needle. The protein concentration was determined by using the Bradford assay, with bovine serum albumin (BSA), as standard. For Western blotting, $50 \mu \mathrm{g}$ of total protein was separated by electrophoresis in a $12 \%$ SDS-PAGE gel, after denaturation at $95{ }^{\circ} \mathrm{C}$ for $5 \mathrm{~min}$ in Laemmli buffer, and electrophoretically transferred to PVDF membranes. After blocking with $5 \%$ milk in TBST $(50 \mathrm{mM}$ Tris- $\mathrm{HCl}, \mathrm{pH} 8$, $154 \mathrm{mM} \mathrm{NaCl}$, and $0.1 \%$ Tween 20) for $2 \mathrm{~h}$ at room temperature, membranes were incubated overnight at $4{ }^{\circ} \mathrm{C}$ with specific antibodies. Membranes were washed three times with TBST for $5 \mathrm{~min}$ and incubated for $1 \mathrm{~h}$ with the respective secondary antibodies. Afterward, membranes were reacted with the ECF detection system (Healthcare Life Sciences, Buckinghamshire, UK) and visualized using an enhanced chemiluminescence detection system (VersaDoc, from Bio-Rad). Densities for each band were calculated with the Quantity One Software (Bio-Rad).

Isolation of Rat Liver Mitochondria. Mitochondria were isolated from the livers of male Wistar rats by conventional differential centrifugation. ${ }^{24}$ Livers were harvested and homogenized with buffer medium containing $250 \mathrm{mM}$ sucrose, $10 \mathrm{mM}$ HEPES ( $\mathrm{pH} 7.4$ ), $1 \mathrm{mM}$ EGTA, and $0.1 \%$ lipid-free BSA. The $\mathrm{pH}$ was adjusted to 7.2, EGTA and BSA being omitted from the final washing medium. The protein content was determined by the biuret method, using BSA as a standard. ${ }^{25}$

Oxygen Consumption. A Clark-type oxygen electrode connected to a suitable recorder in a $1 \mathrm{~mL}$ thermostatted, water-jacketed, and closed chamber was used to measure the oxygen consumption of isolated liver mitochondria. ${ }^{26}$ Mitochondria were suspended at a concentration of $1.5 \mathrm{mg} / \mathrm{mL}$ in respiratory medium comprising $135 \mathrm{mM}$ sucrose, $65 \mathrm{mM} \mathrm{KCl}, 2.5 \mathrm{mM} \mathrm{MgCl}, 5 \mathrm{mM} \mathrm{KH}_{2} \mathrm{PO}_{4}$, and $5 \mathrm{mM}$ HEPES ( $\mathrm{pH}$ 7.2). The phenolic compounds were preincubated with mitochondria for $2 \mathrm{~min}$ before the respiratory substrate. The respiratory substrates, glutamate/malate $(5 \mathrm{mM})$ or succinate $(5 \mathrm{mM})$ plus rotenone $(3 \mu \mathrm{M})$, were added to the system to energize mitochondria, while $\mathrm{ADP}(83.3 \mathrm{nmol} / \mathrm{mg}$ protein $)$ was used to induce state 3 . In order to uncouple respiration and measure the maximal electron transfer rate through the respiratory chain, FCCP $(1 \mu \mathrm{M})$ was added. The respiratory control ratio (RCR) is a measure of oxidative phosphorylation coupling and is calculated as the rate between state 3 and state 4 . The ADP/O ratio represents the oxygen consumed during state 3 respiration and is an indication of the efficiency of the phosphorylative system. ${ }^{27}$

Measurement of Mitochondrial Transmembrane Potential. The mitochondrial transmembrane potential $(\Delta \Psi)$ was monitored indirectly, through the activity of the lipophilic cation tetraphenylphosphonium $\left(\mathrm{TPP}^{+}\right)$, using a $\mathrm{TPP}^{+}$selective electrode as previously described. ${ }^{28}$ Mitochondrial protein $(1.5 \mathrm{mg}$ ) was suspended in reaction medium composed of $125 \mathrm{mM}$ sucrose, $65 \mathrm{mM} \mathrm{KCl}, 5 \mathrm{mM} \mathrm{KH_{2 }} \mathrm{PO}_{4}$, $2.5 \mathrm{mM} \mathrm{MgCl}_{2}$, and $5 \mathrm{mM}$ Hepes $\left(\mathrm{pH} \mathrm{7.4,} 30^{\circ} \mathrm{C}\right.$ ), and supplemented with $3 \mu \mathrm{M} \mathrm{TPP}^{+}$. Phenol compounds were added to mitochondria for $1 \mathrm{~min}$, followed by $10 \mathrm{mM}$ glutamate/malate or $10 \mathrm{mM}$ succinate (plus $3 \mu \mathrm{M}$ rotenone). In order to initiate state $3, \mathrm{ADP}(83.3 \mathrm{nmol} / \mathrm{mg}$ protein) was added. Assuming a Nernst distribution of the ion across the membrane electrode, the equation proposed by Kamo et al. ${ }^{29}$ yielded the values for transmembrane electric potential.

Induction of the Mitochondrial Permeability Transition Pore. The induction of the mitochondrial permeability transition (MPT) pore leads to mitochondrial swelling, which can be followed by the alterations in pseudoabsorbance of the mitochondrial suspension. $^{30}$ The turbidity of the mitochondrial suspension was measured at $540 \mathrm{~nm}$ in a JASCO V-560 spectrophotometer. Mitochondrial protein $(1.5 \mathrm{mg} / \mathrm{mL})$ was incubated at $30^{\circ} \mathrm{C}$, in a reaction medium containing $200 \mathrm{mM}$ sucrose, $10 \mathrm{mM}$ Tris-MOPS ( $\mathrm{pH} 7.4$ ), $10 \mu \mathrm{M}$ EGTA, $1 \mathrm{mM} \mathrm{KH}_{2} \mathrm{PO}_{4}, 1.5 \mu \mathrm{M}$ rotenone, and $2.5 \mathrm{mM}$ succinate, both in the absence and in the presence of the phenolic compounds to be tested. Mitochondrial swelling was induced when calcium $(20 \mu \mathrm{M})$ was added to the system, about $60 \mathrm{~s}$ later. As a control, cyclosporin $\mathrm{A}(1 \mu \mathrm{M})$, the specific MPT pore inhibitor, ${ }^{31}$ was preincubated with the mitochondrial preparation in the presence of the highest concentration of the test compound observed to induce mitochondrial swelling.

Statistical Analysis. Data was loaded to the GraphPad Prism 4.0 program (GraphPad Software, Inc.), all results being expressed as the means \pm SEM, and analyzed by one way ANOVA with the Bonferroni multiple comparison post-test. Values with $p<0.05$ were considered as statistically significant.

\section{RESULTS}

Effects of Phenolic Compounds on Cell Proliferation. In order to choose the concentrations of the parent and derivative compounds (Figure 1) to be used in the different experiments, preliminary assays with a wide range of concentrations have been performed and demonstrated that concentrations of the test compounds between $25 \mu \mathrm{M}$ and $75 \mu \mathrm{M}$ inhibit the proliferation of the human cancer cell lines investigated. Concentrations lower 
BJ

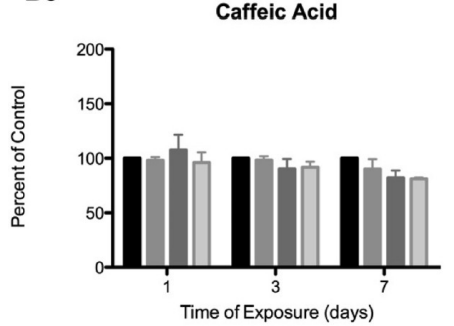

MCF-7

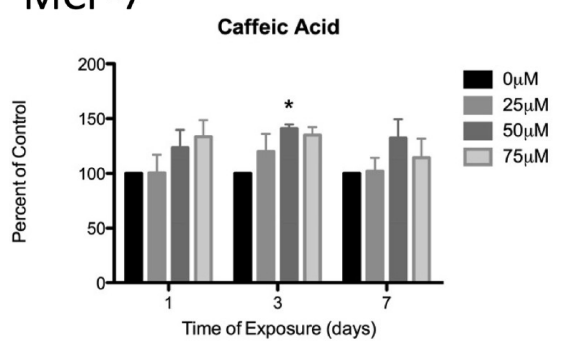

MDA-MB-231

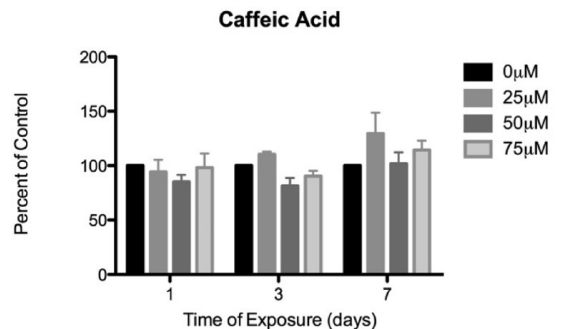

HS 578T
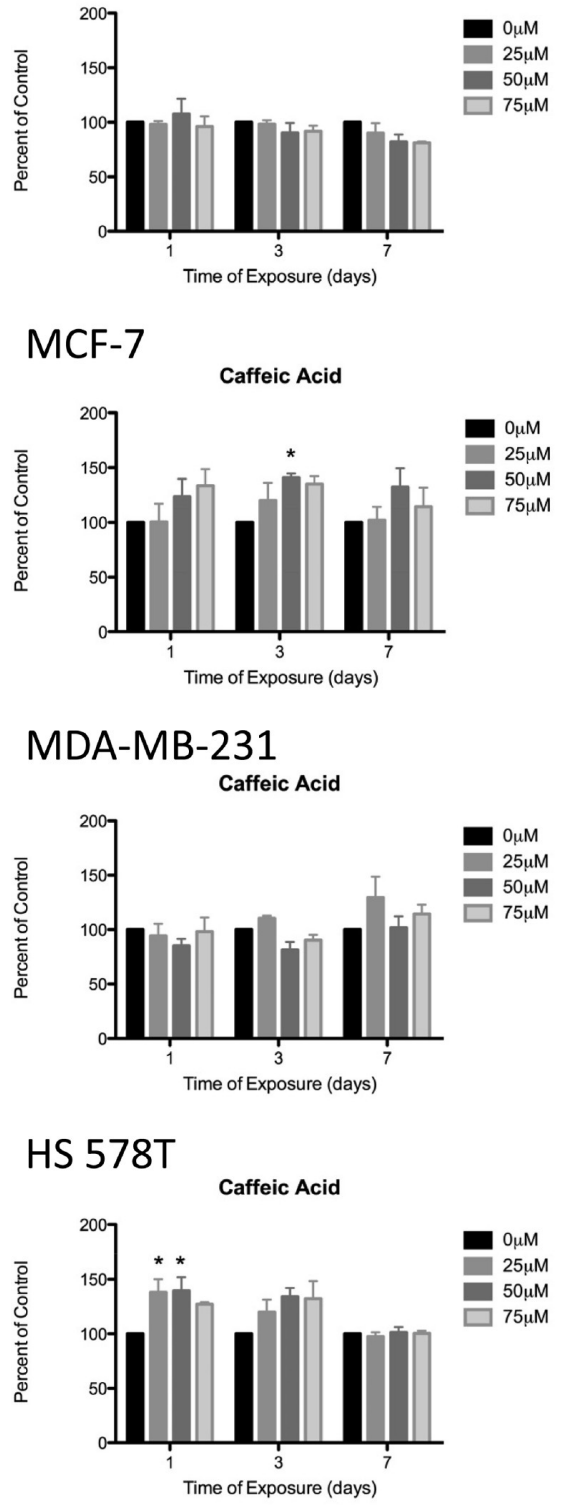

Hexyl Caffeate

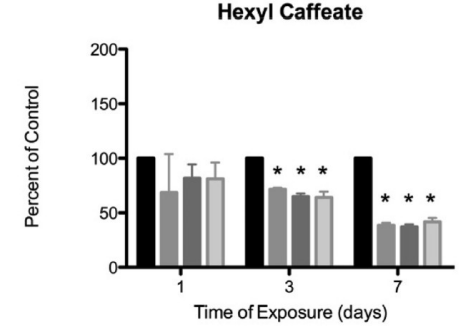

Hexyl Caffeate

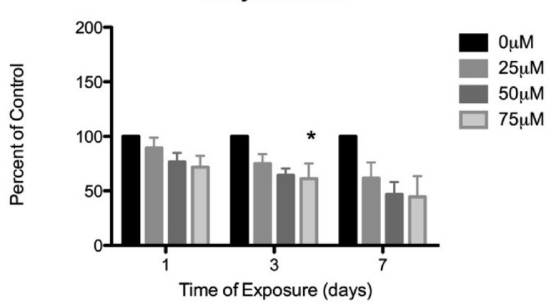

Hexyl Caffeate
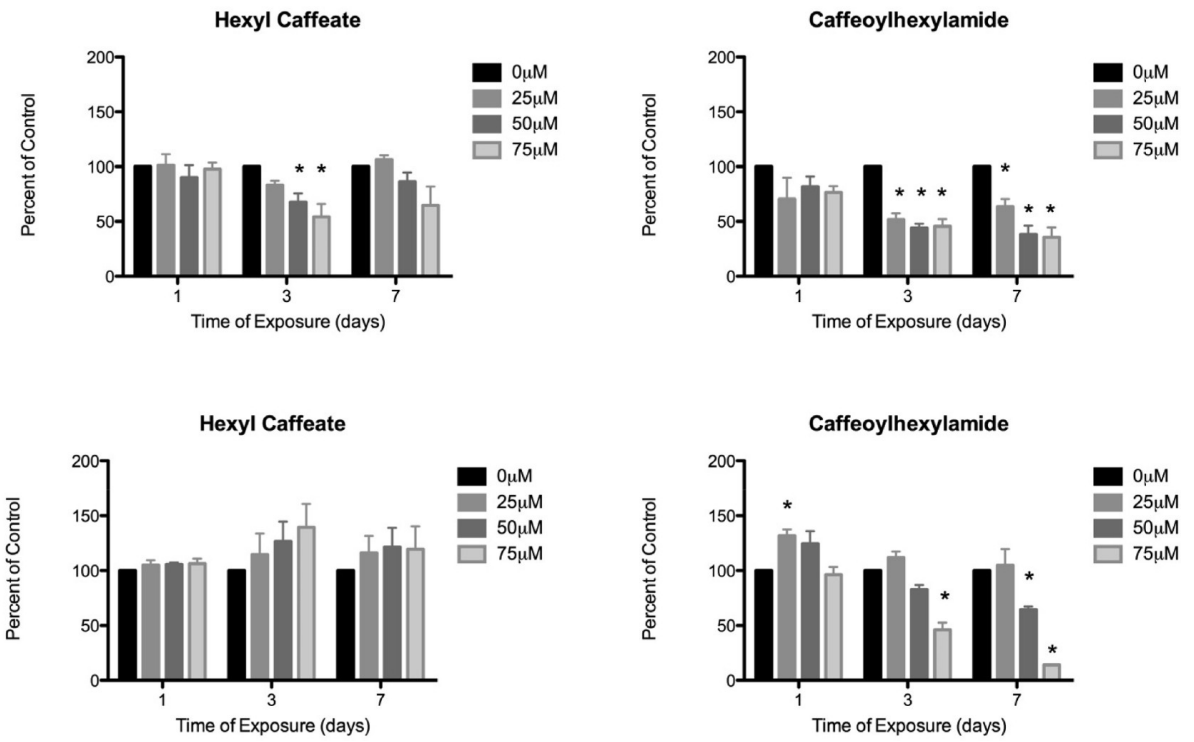

Figure 2. Antiproliferative effect of caffeic acid derivatives. Cells were incubated with a range of concentrations up to $75 \mu \mathrm{M}$ during 1,3 , and 7 days. Cell proliferation was accessed by the sulforhodamine B (SRB) colorimetric assay as described under Materials and Methods and plotted against the time of exposure and concentration of caffeic acid and derivatives. The control value for each time point was determined as $100 \%$ to account for the differential proliferation of the cell lines in study. Data presented as the means \pm SEM of four different experiments. Samples identified by asterisks $\left({ }^{*}\right)$ denote a significant difference from controls $(p<0.05)$.

than $25 \mu \mathrm{M}$ did not show any growth-inhibiting effect in any cell line tested, while concentrations higher than $75 \mu \mathrm{M}$ resulted in major induction of cell death for both noncancer and cancer cells, hence demonstrating nonspecificity (data not shown). Therefore, for further experiments, phenolic acids and their derivatives were used at concentrations between 25 and $75 \mu \mathrm{M}$ and were incubated for 1,3 , and 7 days with a panel of human breast cancer cells (MCF-7, MDA-MB-231, and HS578T) and with nonneoplastic cells (BJ).

From the proliferation curves obtained (Figures 2 and 3 ), one evident finding is that the parent compounds, caffeic (CA) and ferulic acid (FA), did not inhibit the proliferation of any of the four cell lines used. In fact, stimulation of cell proliferation was observed in some cases, one particular example being the effect of
25 and $50 \mu \mathrm{M}$ caffeic acid, which caused a 1.5-fold increase in HS578T cell proliferation after 1 day of treatment (Figure 2).

Among the caffeic acid derivatives, hexyl caffeate (HC) and caffeoylhexylamide (HCA) showed a general inhibition of proliferation of all cell lines tested (Figure 2). The most striking effect was seen with HCA, which, after 7 days of incubation caused around $80-90 \%$ inhibition of proliferation of MCF-7, BJ, and HS578T cells. Interestingly, HC showed a stronger effect on BJ fibroblasts (with around 50\% inhibition of proliferation for 7 days of incubation) and had no effect on HS578T breast cancer cells.

Ferulic acid derivatives hexyl ferulate (HF) and feruloylhexylamide (HFA) showed dissimilar effects according to the cell line tested (Figure 3). MCF-7 cells were particularly susceptible 
BJ
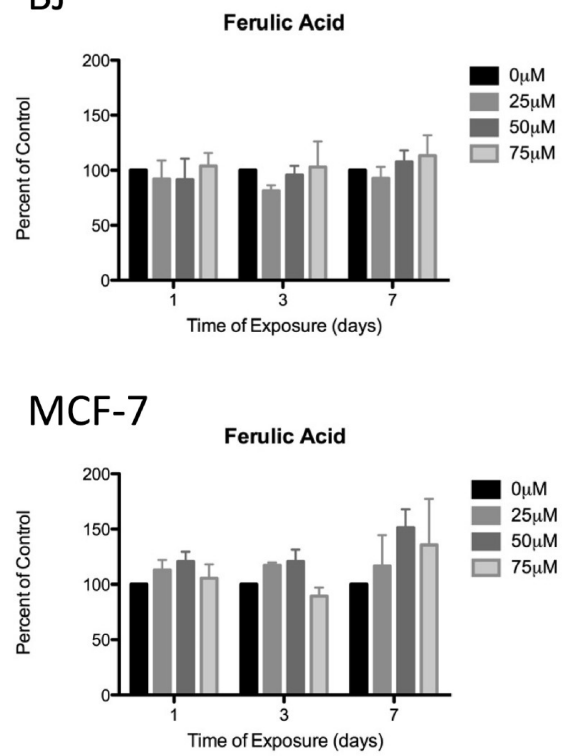

MDA-MB-231
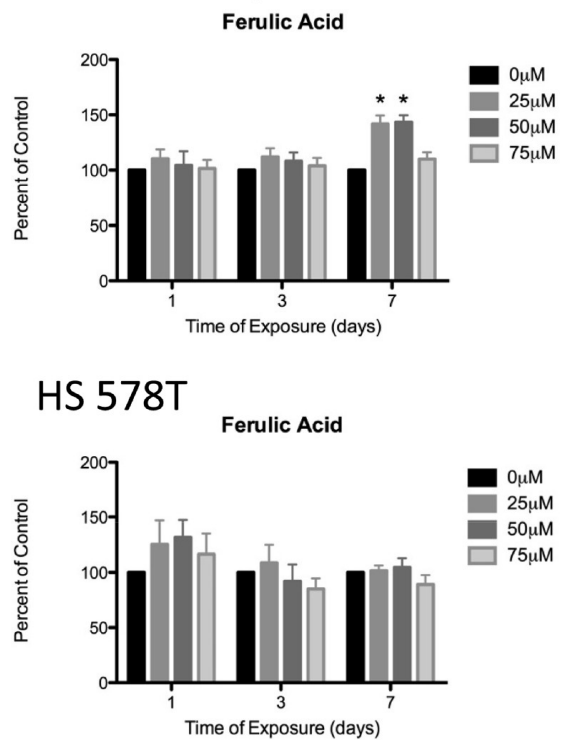
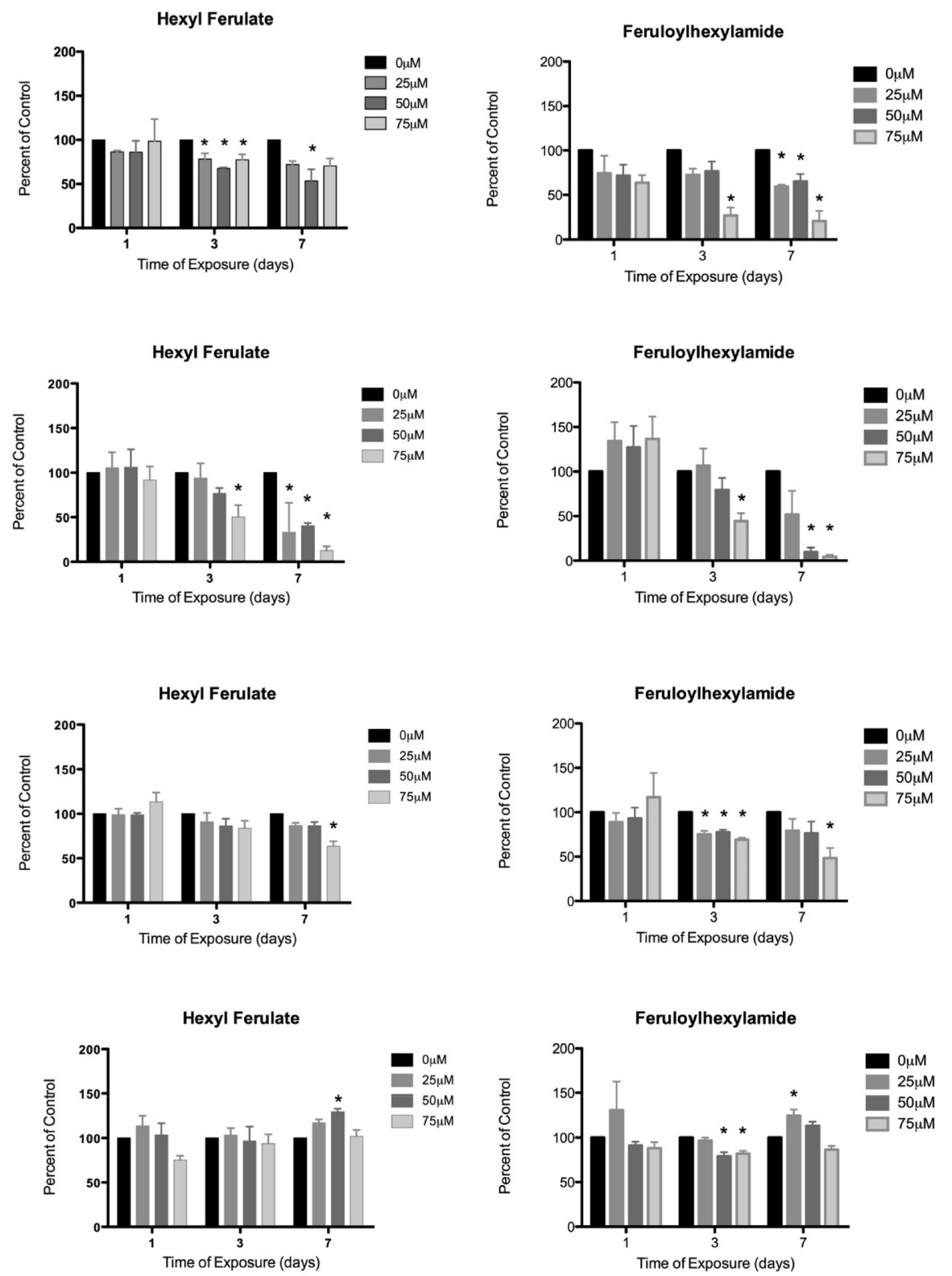

Figure 3. Effects of ferulic acid and derivatives on cell proliferation (see Materials and Methods and the Figure 2 legend for technical details). The control value for each time point was determined as $100 \%$ to account for the differential proliferation of the cell lines in the study. Data presented as the means \pm SEM of four different experiments. $\left(^{*}\right)$ Significant difference from controls $(p<0.05)$.

to both compounds, especially for longer incubation periods, which HS578T appearing to be largely insensitive, with the exception of a $25 \%$ inhibition of proliferation observed when HFA was incubated for 3 days (Figure 3).

Effects of Phenolic Compounds on Cell Cycle and Apoptosis. Although very indicative, inhibition of cell proliferation as measured by the sulforhodamine B method does not distinguish between cell death and cell cycle inhibition. Hence, in order to gain deeper insights into the mechanisms by which the test compounds decrease cell proliferation (Figures 2 and 3), cell cycle and apoptosis were analyzed. To this end, a single concentration of the test compounds was chosen. The different human tumor and nontumor cell lines were incubated with $75 \mu \mathrm{M}$ of the test compounds for 2 and 4 days, and their cell cycle status analyzed by flow cytometry. Two and four days of treatment time were chosen for the experiments in order to have both a short and a long-time exposure, while avoiding the loss of a large number of cells due to extensive cell death.

In agreement with cell proliferation assays (Figures 2 and 3), the parent compounds CA and FA did not have any impact on the cell cycle of any of the cell lines studied (Figures 4 and 5). The increased cell proliferation observed by the SRB technique was not confirmed in some cases by the altered cell cycle. The two CA derivatives, $\mathrm{HC}$ and $\mathrm{HCA}$, induced an increase in the percentage of cells in S-phase for the BJ cell line for the longest incubation period, although no apoptotic DNA (sub-G1) was measured. In MCF-7 cells, 48 h of treatment with HC resulted in S-phase cell cycle arrest, while $96 \mathrm{~h}$ of incubation resulted in cell death. In this same cell line, another very significant result was observed for $96 \mathrm{~h}$ of incubation, when HCA caused an increase in the sub-G1 
BJ

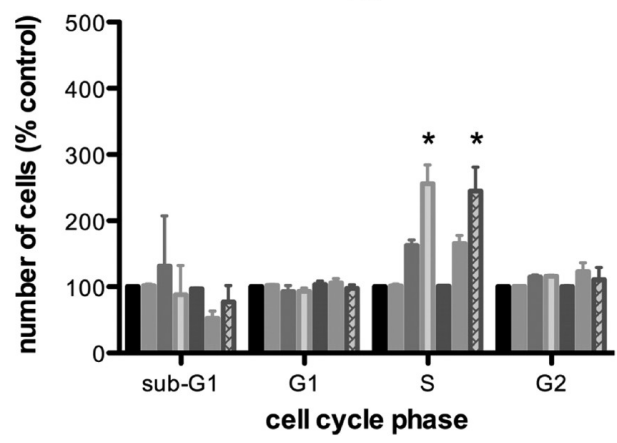

MDA-MB-231

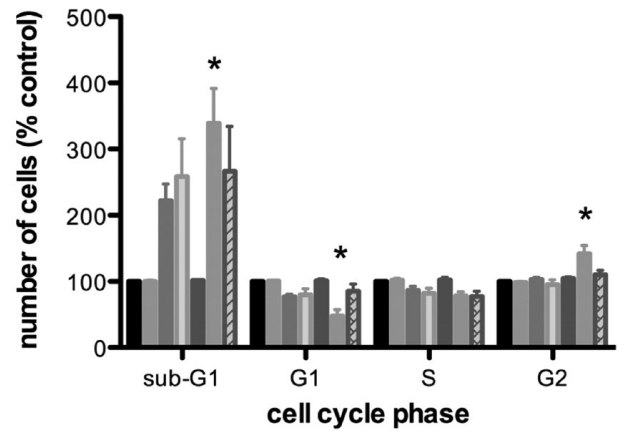

MCF-7

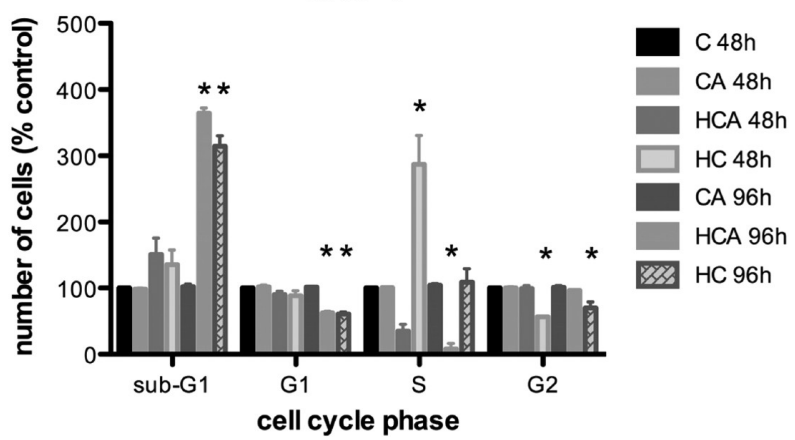

HS 578T

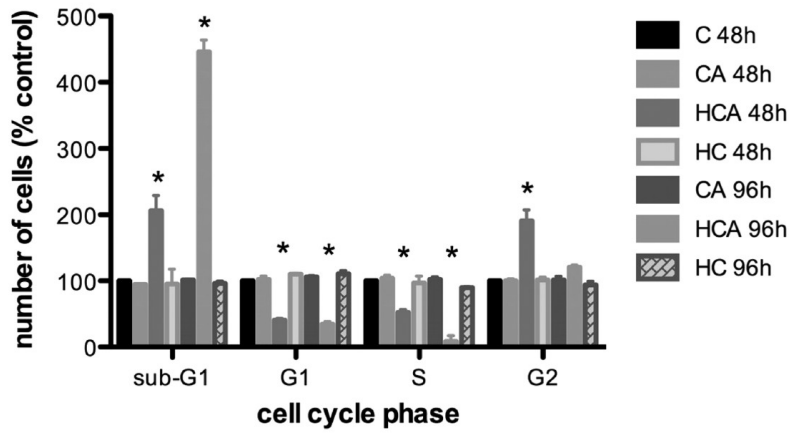

Figure 4. Cell cycle analysis of BJ, MCF-7, MDA-MB-231, and HS578T cells, treated with $75 \mu \mathrm{M}$ of caffeic acid and derivatives for 48 and $96 \mathrm{~h}$. The cell cycle was analyzed by flow cytometry. The values shown are the averages of four independent experiments; bars indicate the standard error of the mean \pm SEM. $\left({ }^{*}\right)$ Significant difference from controls $(p<0.05)$.

BJ

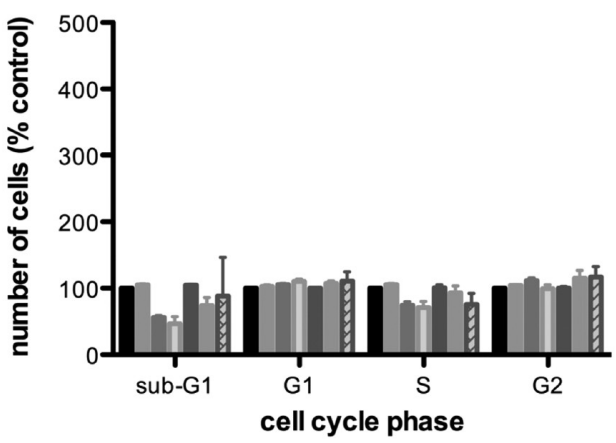

MDA-MB-231

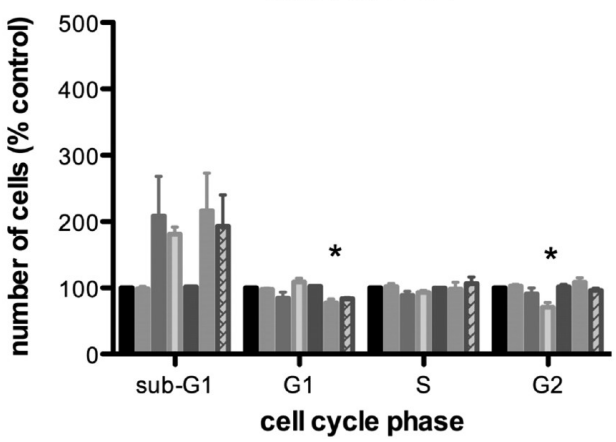

MCF-7
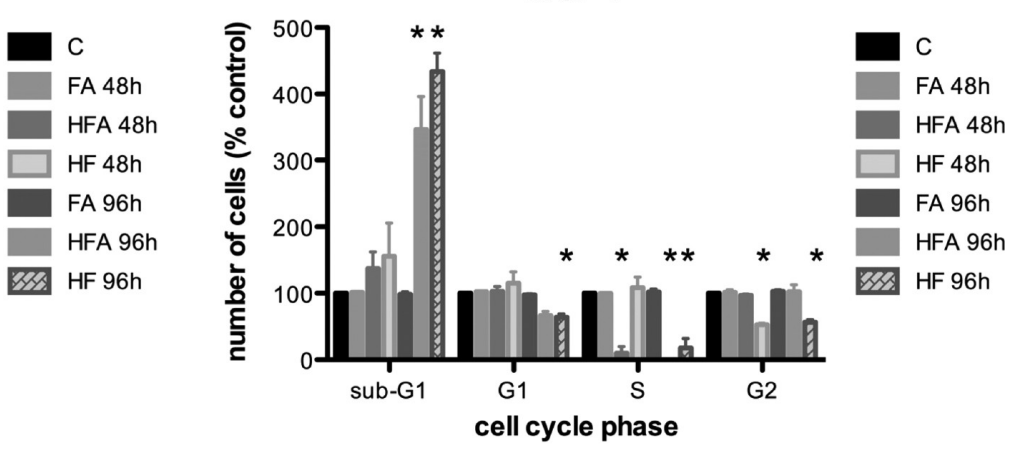

HS 578T

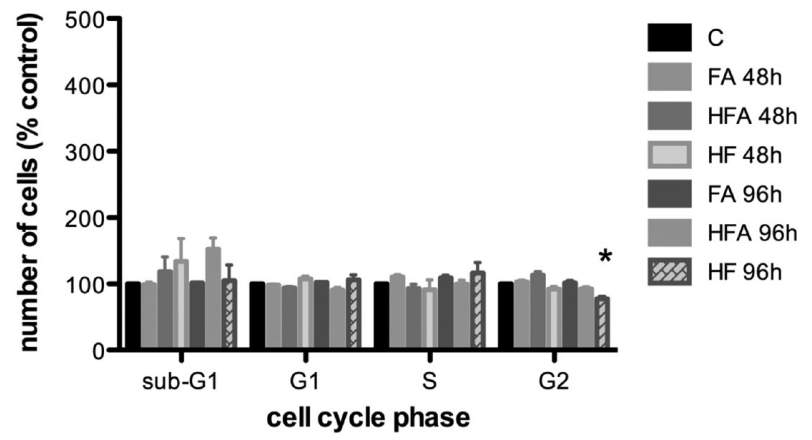

Figure 5. Cell cycle analysis of BJ, MCF-7, MDA-MB-231, and HS578T cells, treated with $75 \mu \mathrm{M}$ ferulic acid and derivatives for 48 and $96 \mathrm{~h}$. The cell cycle was analyzed by flow cytometry. The values shown are the averages of four independent experiments; the bars indicate the standard error of the mean \pm SEM. $\left(^{*}\right)$ Significant difference from controls $(p<0.05)$. 
peak, suggesting cell death by apoptosis, and a marked decrease in cells in S phase (Figure 4). The decreased proliferation caused by $\mathrm{HC}$ and HCA in MDA-MB-231 cells (Figure 4) was translated into an 2- to 3-fold increase in apoptotic sub-G1 peaks for both compounds (48 and $96 \mathrm{~h}$ ), although statistical significance was only observed for $96 \mathrm{~h}$ of incubation with HCA. A small, but significant decrease in cells in G1 phase and an increased number of cells in G2 cells caused by HCA for $96 \mathrm{~h}$ was also observed (Figure 4). Finally, HCA showed mixed effects on HS578T cells, with a significant increase in the number of cells in sub-G1 for 48 $\mathrm{h}$ and $96 \mathrm{~h}$, a decreased number of cells in G1 and S phases for both times studied, and an increased number of cells in G2 phase for $48 \mathrm{~h}$ (Figure 4). Confirming the lack of effects on cell proliferation (Figure 2), HC had no effects on the HS578T cell line (Figure 4).

Ferulic acid derivatives (HF and HFA) were less effective than caffeic acid derivatives concerning cell cycle effects. The BJ fibroblast cell cycle was not affected by any of the compounds studied, whereas HS578T suffered a minor, but significant, decrease in the number of cells in G2 phase when treated with $\mathrm{HF}$ for $96 \mathrm{~h}$ (Figure 5). Effects were somehow more visible for the MDA-MB-231 cell line, where a nonstatistically significant increase in cells in sub-G1 phase was observed for both compounds during 48 and 96 h; an approximately $10 \%$ decrease in cells in G1 phase (HFA, $96 \mathrm{~h}$ ) and around $20 \%$ decrease in cells in G2 phase (HF, $48 \mathrm{~h}$ ) were observed (Figure 5). Finally, most of the effects from ferulic acid derivatives were observed on MCF-7 cells. In this case, a very significant increase in apoptotic sub-G1 was observed for both compounds for $96 \mathrm{~h}$ of incubation time. A large decrease in the number of cells in $S$ phase was also observed for $48 \mathrm{~h}$ (HFA) and $96 \mathrm{~h}$ (HFA and HF). In fact, no cells in S phase were detected after $96 \mathrm{~h}$ incubation with HFA (Figure 5).

By using Hoechst 33342 to label cell nuclei, apoptotic chromatin condensation can be detected. We performed this protocol after $48 \mathrm{~h}$ of incubation and counted apoptotic-like nuclei. One major limitation of this method is that only adherent cells are counted, which strongly minimizes the extent of apoptosis. Nevertheless, it was possible to observe that HF was the most potent compound inducing chromatin apoptotic alterations in MCF-7 (25.1 $\pm 3.7 \%$ apoptotic cells vs $0 \pm 0 \%$ for control) and MDA-MB-231 (18.6 $\pm 4.9 \%$ apoptotic cells vs $0 \pm$ $0 \%$ for control) cells. For this same time point, HCA also caused an increase in the percentage of apoptotic nuclei in MDA-MB231 cells $(25.1 \pm 3.7 \%$ apoptotic cells vs $0 \pm 0 \%$ for control).

Interestingly, by investigating by vital microscopy the effects of the two parent compounds and the two of the more active derivatives (HCA and HF, $75 \mu \mathrm{M}$ ), the decrease of MCF-7 proliferation is accompanied by altered cell shape, namely, rounding up of cells, membrane blebbing, and loss of mitochondrial membrane potential (indicated by white arrows in Figure 6), which are typically from an apoptotic phenotype. From Figure 6, it is seen that HF causes the highest degree of cell alterations, including loss of mitochondrial TMRM accumulation, although, in this regard, HCA is shown to induce more visible effects on the breast cancer cell MCF-7 than on the BJ line. The lower panel of Figure 6 shows in more detail the alterations in mitochondrial membrane potential caused by $75 \mu \mathrm{M}$ HCA in MDA-MB-231 cells, as compared with a small, if any, effect of $75 \mu \mathrm{M}$ HF on this cell line after a $48 \mathrm{~h}$ incubation. Mitochondrial depolarization is seen in TMRM labeled cells treated with HCA.

After the initial set of experiments, the MCF-7 cell line was chosen for further experiments in order to clarify the activation of signaling pathways involved in apoptosis and cell cycle regulation. Overall, this cell line was the most affected in terms of the inhibition of proliferation and the cell cycle. MCF-7 cell death caused by $75 \mu \mathrm{M}$ HCA involves caspase 8 and 9 activation, as observed by Western blotting. Cleaved, active fragments were detected for $96 \mathrm{~h}$ but not for $48 \mathrm{~h}$ of HCA treatment for both caspases (Figure 7), which suggests involvement of the intrinsic and extrinsic apoptotic pathways. Cell death was also confirmed by a decrease in the band corresponding to full length poly(ADPribose) polymerase (PARP) for $96 \mathrm{~h}$ of treatment. Although HCA appears to increase $\mathrm{p} 53$ protein in total extracts after $96 \mathrm{~h}$ of treatment, no increase in the band corresponding to p21 was detected. The pro-apoptotic protein Bax and the antiapoptotic protein $\mathrm{Bcl}-2$ appeared not to be affected by HCA treatment for 48 or $96 \mathrm{~h}$ (Figure 7). The results were somewhat different when $75 \mu \mathrm{M}$ HF was incubated with MCF-7 cells. No caspase 8 active fragment was detected for 48 and $96 \mathrm{~h}$, although an active caspase 9 fragment appears to be present for $48 \mathrm{~h}$ (but not $96 \mathrm{~h}$ ) of treatment, simultaneously with a visible increase in p53 and Bax protein bands.

Regarding the two parent compounds (CA and FA), the most noticeable change was an apparent increase in p53 for $48 \mathrm{~h}$ and $96 \mathrm{~h}$, although no alterations in other proteins were noted.

Effect of the Phenolic Compounds on Isolated Mitochondrial Fractions. The final step of the present study was investigating direct mitochondrial effects of the test compounds by using isolated liver mitochondrial fractions as a biological model. As end points for mitochondrial toxicity, mitochondrial respiration (state 3 , state 4 , and uncoupled), and $\Delta \Psi$ (maximumattained $\Delta \Psi, \mathrm{ADP}$-induced depolarization, and phosphorylative lag phase) parameters were measured.

Regarding mitochondrial respiration, the effects of all test compounds on mitochondrial bioenergetics were made by using complex I (glutamate-malate) and complex II (succinate) substrates. When the former were used, significant alterations of mitochondrial respiration were observed with the parent compound CA $(50 \mu \mathrm{M})$, which slightly decreased state 3 respiration $(90.2 \pm 2.1 \%$ of control value, $p<0.05)$, with $\mathrm{HF}$, which increased state 3 respiration (to $113.3 \pm 3.5 \%$ of control, $p<0.05)$, and with HFA $(75 \mu \mathrm{M})$, which not only increased FCCP-uncoupled respiration (to $154.5 \pm 14.1 \%$ of control, $p<$ $0.05)$ but also decreased the RCR ( $69.2 \pm 5.4 \%$ of control values, $p<0.05)$. It is important to notice that in this former case, differences observed in states 3 and 4 respiration did not achieve statistical significance per se (data not shown). When succinate was used as substrate in the presence of rotenone, a few alterations were observed. HF $(75 \mu \mathrm{M})$ decreased the RCR (to $74.8 \pm 6.1 \%$ of the control value, $p<0.05$ ), which was mostly caused by an increase in state 4 respiration (146.2 $\pm 16.3 \%$ of control values, $p<0.05$ ).

Regarding the generation of the transmembrane electric potential $(\Delta \Psi)$, the effects of the different compounds tested were minimal. Only one alteration was measured, which was a decreased ADP-induced depolarization (down to $82.9 \pm 4.8 \%$ of control values, $p<0.05$ ) caused by HCA.

Next, the phenolic compounds were investigated according to their ability to induce the MPT. MPT pore opening has been closely related with the mitochondrial toxicity of different xenobiotics and with the induction of cell death. ${ }^{32}$ Calcium-induced mitochondrial swelling is one hallmark of MPT induction and can be followed spectrophotometrically. Figure 8 (right panel) shows a representative recording of $\mathrm{MPT}$ induction after calcium 
BJ

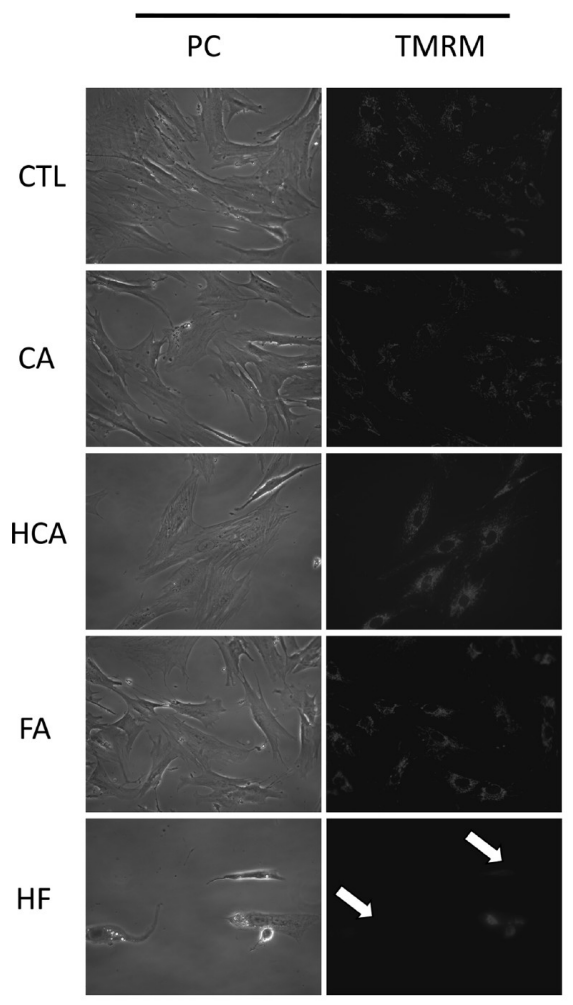

MCF-7
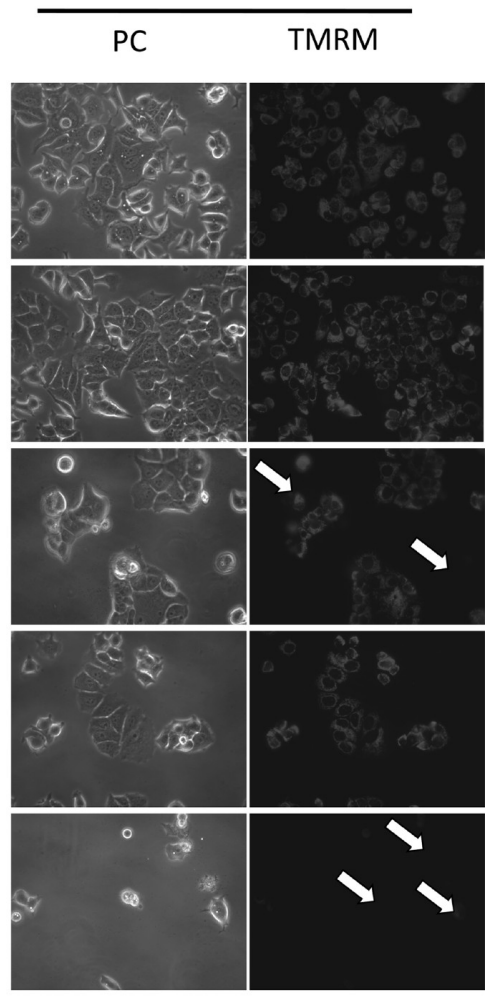

MDA-MB-231

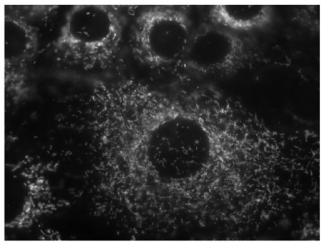

Control

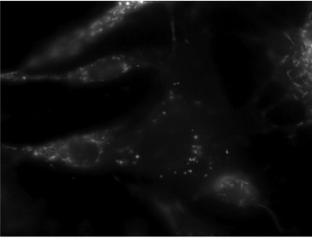

HCA

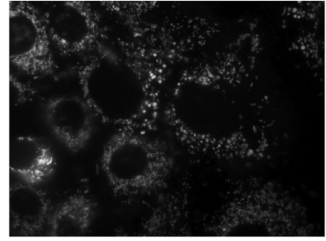

HF

Figure 6. Epifluorescence micrographs showing the effects of caffeic and ferulic acids and the derivatives HCA and HF on cell morphology and mitochondrial polarization in BJ and MCF-7 cell lines (upper set of images) and MDA-MB-231 (lower set of images). Cells were treated with ethanol vehicle only $(0.01 \% \mathrm{v} / \mathrm{v}$, control) or $75 \mu \mathrm{M}$ of the test compounds for $48 \mathrm{~h}$. Cells were labeled with TMRM, which is accumulated by polarized mitochondria. Note that the loss of mitochondrial polarization is first characterized by increased cytosolic TMRM fluorescence, followed by complete loss of cellular labeling, indicated in the upper set of images by white arrows. Mitochondrial depolarization is also visible in the lower images, when MDAMB-231 cells were incubated with $75 \mu \mathrm{M}$ HCA but not with $75 \mu \mathrm{M}$ HF. The images are representative of three independent preparations.

addition and the effect of preincubation with the different test compounds. In this regard, the results were somehow unexpected. For example, the parent compound FA induced the MPT as demonstrated by increased calcium-dependent mitochondrial swelling amplitude; this effect was abolished in the derivatives, although HFA caused a nonstatistically significant increase in calcium-induced swelling (Figure 8C and D). As for caffeic acid derivatives, only $\mathrm{HC}$ presented in vitro MPT-inducing properties for the highest concentration tested (Figure $8 \mathrm{~A}$ and $\mathrm{B}$ ). A negative control was made with cyclosporin A (CsA), the specific MPT inhibitor, $^{31}$ preincubated with mitochondria and the highest concentrations of the compounds to be tested. Swelling amplitude was decreased with CsA (Figure 8).

\section{DISCUSSION}

Phenolic acids have been recognized not only for their properties on the prevention or delay of in vitro and in vivo deleterious oxidation processes, due to intrinsic free radical scavenging and antioxidant activity, but also for their cytotoxic effects toward neoplastic cells in particular. Interestingly, it is also known that low-molecular-weight phenolic acids can produce both cytoprotective and cytotoxic effects in different settings, ${ }^{33}$ including cytotoxicity toward breast cancer in in vitro and in vivo experiments. ${ }^{34}$ However, details are still scarce regarding their mechanisms of action.

The present work was aimed at studying the cytotoxicity of a series of caffeic and ferulic acid ester and amides lipophilic derivatives ${ }^{15}$ toward human breast cancer cells, as well as their direct effects on isolated hepatic mitochondrial fractions. The objective was to identify whether the molecular alterations aimed at increasing the lipophilicity of the test compounds would render them more active toward breast cancer cells also by increasing their reactivity toward mitochondria.

Hexylcinnamic amides were synthesized in moderate/high yields by a one-pot condensation reaction that occurs in equimolar 
$48 \mathrm{~h}$

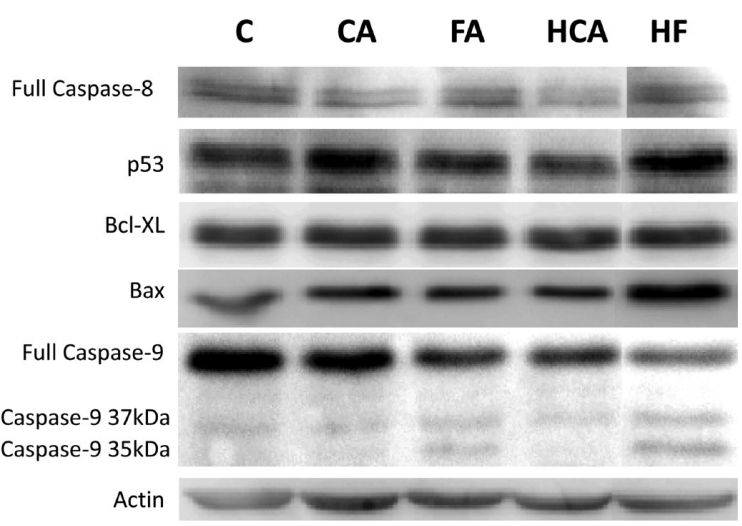

$96 h$

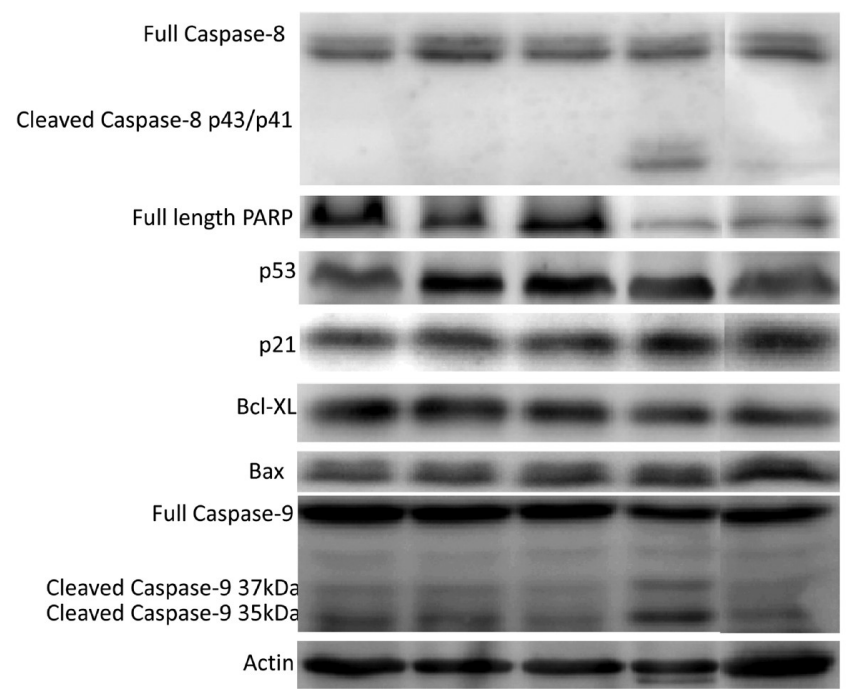

Figure 7. Detection by Western blotting of proteins relevant for alterations in cell death and cell cycle in total fractions from MCF-7 cells. Protein loading was the same in each lane, confirmed by actin labeling. Cells were incubated with the test compounds for 48 and $96 \mathrm{~h}$. The results are representative of 3-4 separate experiments.

amounts between the corresponding cinnamic acids and hexylamine. The coupling reagent selected for carboxylic acid activation was (benzotriazol-1-yloxy)tris (dimethylamino)phosphonium hexafluorophosphate (BOP). ${ }^{35}$ As the classic acid-catalyzed Fisher esterification is not appropriate when using long chain alkyl alcohols, the hexylcinnamic esters were obtained by base-catalyzed alkylation from the corresponding cinnamic acids with in situ generation of the carboxylate anions and subsequent reaction, at room temperature, with hexylbromide. ${ }^{36,37}$ The hydrophilic parent compounds caffeic (CA) and ferulic (FA) acids are thus modified by adding an alkyl chain through an ester or an amide bond (Figure 1), originating hexyl caffeate ( $\mathrm{HC}$ ), hexyl ferulate (HF), caffeoylhexylamide (HCA), and feruloylhexylamide (HFA), respectively. The synthesized compounds were purified and then identified by both NMR and EI-MS, this data being in accordance with previous reports. ${ }^{15}$ Raman spectra were also obtained for the solid samples of the synthesized compounds (Figure S1, Supporting Information).

As expected, the structural modification performed in the phenolic systems led to an increase in lipophilicity, which is expected to favor the intracellular accumulation of the compounds. In fact, CA $(\log D 0.16)$ and FA $(\log D 0.42)$ have relative low lipophilicity compared to that of the new compounds: HC ( $\log P$ 3.91), HCA $(\log P$ 3.61), HF ( $\log P$ 4.05), and HFA $\left(\log P\right.$ 3.58). ${ }^{15}$

Despite the facts that the parent compounds revealed no toxicity toward the cell lines studied, the derivatives were found to exhibit distinct effects on cell proliferation depending on the cell line studied. The experiments performed in noncancerous cells (the BJ cell line) indicate that some of these new compounds, particularly the caffeate derivatives, can display some cell growth inhibition toward normal cells, affecting both cell density and viability. However, these effects were mostly based on cell cycle arrest rather than cell death (Figures 2 and 4), which is demonstrative of some sparing effect on nontumor cells. Cell death caused by the phenolic derivatives was confirmed by mitochondrial depolarization (Figure 6), sub-G1 peaks (Figures 2 and 3), and chromatin condensation. Interestingly, it can be seen from Figures 2 and 3 that amide derivatives of both caffeic and ferulic acids are more active toward the inhibition of cancer cell proliferation.

In the present study, three different breast cancer cell lines were used, divided into estrogen receptor-positive breast cancer (MCF-7) and estrogen receptor-negative breast cancer cells (MDA-MB-231 and HS578T). MCF-7 cells were shown to be the more susceptible ones to the two ferulic acid derivatives (Figure 3). Knowing that some drugs can repress estrogen receptor alpha $(\mathrm{ER} \alpha)$ and cyclin D1-dependent transcription, leading to G1 cell cycle arrest, ${ }^{38}$ it can be suggested that the test compounds can interact with estrogen receptors or with downstream signaling pathways, contributing to the increased susceptibility of MCF-7 cells. Other biophysical properties can also be responsible for the differential cell response to chemotherapy, including alterations in the composition of cell membrane lipids, which can decrease intracellular drug transport via diffusion. ${ }^{39}$ Moreover, multidrug resistance may contribute to the possible different drug toxicities, if the proteins contributing to such resistance are not equally present in the cell lines tested. ${ }^{40}$

By focusing on the mechanisms of apoptotic signaling triggered by the test compounds on MCF-7 cells, data from cell cycle analysis suggests that the derivatives in the study cause an initial block of $S$ phase. It is known that cell cycle regulators, such as p53, play an important role in the process of apoptosis, regulating the expression of $\mathrm{Bcl}-2$ family proteins that modulate the mitochondrial pathway of apoptosis. ${ }^{41,42}$ The apparent increase in p53 resulting from incubation with $\mathrm{HF}$ ( $48 \mathrm{~h}$, Figure 7) can impact the progression of the cell cycle. Nevertheless, an apparent increase in p53 in MCF-7 cells treated with CA (48 h and $96 \mathrm{~h}$ ) and FA (96 h) was also observed, although no effects were observed in terms of cell cycle or apoptosis, which is line with an absence of effects on Bax or p21 (Figure 7). The results from Figure 7 suggest that HCA is acting in both the intrinsic and extrinsic pathways for apoptosis, although the mechanism is still unknown. The results are not surprising since it has been described that phenolic acids can interact with cell surface receptors such as the tumor necrosis factor related apoptosis inducing ligand (TRAIL), promoting caspase-8-dependent cell death. ${ }^{43}$ In its turn, the data appears to suggest that HF mostly acts through the mitochondrial pathway involving p53 and Bax (Figure 7), and mediated by mitochondrial depolarization (Figure 6) with consequent activation of caspase 9, which is more visible for $48 \mathrm{~h}$, and resulting in increased cell death (Figure 3 and 5).

Since mitochondria are involved at the crossroads of carcinogenesis, cancer chemotherapy, and tumor survival, as well as 

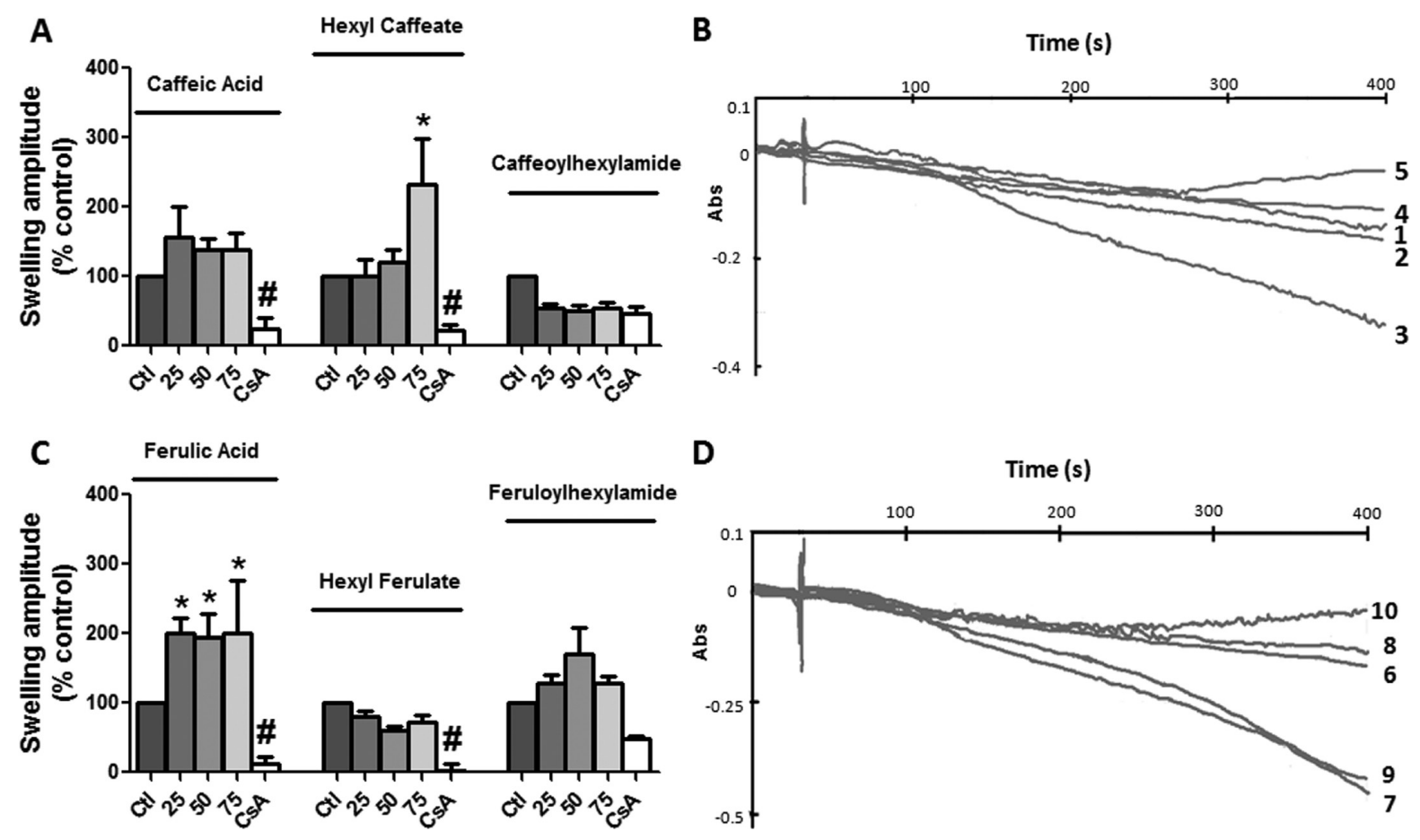

Figure 8. Effects of different concentrations of the test compounds on the calcium-induced MPT pore, as followed by measuring variations in mitochondrial volume. Results are shown for caffeic acid and derivatives (A) and ferulic acid and derivatives (C). Mitochondrial swelling amplitude was calculated as the difference between the baseline absorbance and the absorbance after $400 \mathrm{~s}$. Data are the means \pm SEM of at least five different experiments. Typical recording of the effect of caffeic acid and derivatives (B) and ferulic acid and derivatives (D) on mitochondrial swelling. Mitochondria ( $1.5 \mathrm{mg}$ ) were energized by succinate. After a basal line was established, $20 \mu \mathrm{M}$ calcium was added to induce the MPT pore. Mitochondria were incubated with $75 \mu \mathrm{M}$ phenolic acids. In B, line (1), control; (2), caffeic acid; (3), hexyl caffeate; (4), caffeoylhexylamide; (5), cyclosporin A. In D, line (6), control; (7), ferulic acid; (8), hexyl ferulate; (9), feruloylhexylamide; (10), cyclosporin A. Cyclosporin A was incubated before the addition of calcium and was able to prevent mitochondrial swelling. The recordings shown here are representative of at least five independent mitochondrial preparations.

drug-induced toxicity, we investigated whether the parent compounds and their derivatives could exert direct effects on isolated rat hepatic mitochondria. Although normal liver and cancer cell mitochondria present certain structural and functional differences, ${ }^{44,45}$ we believe that sufficient similarities exist to justify using isolated liver mitochondria as models to gain insight into the interactions of xenobiotic compounds with mitochondria. Also, isolated mitochondrial fractions present the advantage of a much higher isolation yield so that more aspects of mitochondrial function and compound-induced toxicity can be studied with one single isolation procedure. Studies on isolated mitochondrial fractions from nontumor tissues also can supply clues on the toxicity of the test compounds to nontarget organs. Some direct effects of the parent compounds and lipophilic derivatives were observed on mitochondrial bioenergetics, but the most surprising result was an expected induction of the MPT by FA, which was never before reported in the literature. Since no toxic effects of FA on intact cells were observed, this may indicate that FA does interact with mitochondria in intact cells, at least in the concentrations that are able to induce the MPT. The mechanisms by which FA caused MPT induction are unknown at the moment and deserve further attention. Also, with the exception of $\mathrm{HC}$, which caused MPT induction for the highest concentration tested $(75 \mu \mathrm{M})$, the new lipophilic derivatives were shown to be less toxic to isolated mitochondrial fractions regarding MPT induction (Figure 8). Apparently, there was no direct relationship between the toxicity on isolated hepatic mitochondrial fractions and the effects on intact cells, which may mean that this organelle is not part of the main mechanism of cytotoxicity of the new derivatives. We have previously demonstrated that the cell toxicity of the phytochemical berberine presented a good degree of equivalency to the effects observed in isolated hepatic mitochondria, demonstrating in this case a classic example of a compound whose primary mechanism of toxicity relies on mitochondria. ${ }^{21}$ Indirectly, the data on isolated mitochondrial fractions also suggest the relatively low toxicity of the new derivatives for concentrations lower than $50 \mu \mathrm{M}$, which can be a positive sign for further human safety evaluation of these novel molecules. $^{20,46}$

Although our objective of synthesizing lipophilic derivatives with higher ability to interact with cell systems was achieved, further research will be required to define more specifically the mechanisms of action and to propose the use of these novel compounds on cancer prevention and treatment. One particular aspect is the fact that the compounds exerted the majority of their effects on cancer cells at concentrations higher than $25 \mu \mathrm{M}$ and for incubations higher or equal to 3 days. Although this appears to be a high concentration which would be difficult to maintain in the serum for that amount of time, there are clues that may indicate otherwise. For example, the increased lipophilicity of the derivatives tested here may increase their higher persistence in a lipid environment. Although data is not still available on the bioavailability of the derivatives tested here, more has been 
published on the parent compounds themselves since they are present in the human diet. One study suggested that the concentration of caffeic acid in the blood of humans, with a normal intake of food and average coffee intake, is around $2.4 \mu \mathrm{g} / \mathrm{mL}$ or $13 \mu \mathrm{M}^{47}$ Individuals that drink several cups of coffee per day may ingest as much as $500-800 \mathrm{mg}$ of hydroxycinnamic acids per day. ${ }^{48}$ Wang et al. measured caffeic acid plasma concentrations after an I.V. bolus of $4.5 \mathrm{mg} / \mathrm{kg}$ to Sprague-Dawley rats. The peak of plasma concentration was around $22 \mu \mathrm{M}$, although it rapidly decayed within $90 \mathrm{~min} .{ }^{49}$ In order to maintain higher concentrations in the plasma during longer times, one alternative would be liposomal encapsulation, although a series of technical issues still need to be solved. ${ }^{50} \mathrm{~A}$ further approach is that the test compounds may be used jointly with conventional therapies, although the outcome may not always be an increased tumor cell killing.

In conclusion, we have investigated the cytotoxicity of novel lipophilic caffeic and ferulic acid derivatives in human breast cancer cells and in a nontumor cell line. The inclusion of an alkyl chain through an ester or an amide bond on both caffeic and ferulic acid increases their cytotoxicity toward the cell lines studied, especially against the estrogen-positive MCF-7 cell line. The data suggests possible structural modifications in phenolic acids usually present in the human diet, in order to increase their interaction with tumor cells and gain easier access to intracellular targets. We also conclude that from the data obtained, direct toxicity at the mitochondrial level may not be the mechanism of action for the new derivative compounds.

\section{ASSOCIATED CONTENT}

S Supporting Information. Characterization of the compounds by Raman spectroscopy and representive experimental Raman spectra $\left(1100-1800 \mathrm{~cm}^{-1}\right.$, at $\left.25^{\circ} \mathrm{C}\right)$ for four of the tested compounds. This material is available free of charge via the Internet at http://pubs.acs.org.

\section{AUTHOR INFORMATION}

\section{Corresponding Author}

${ }^{*}$ Center for Neuroscience and Cell Biology, Department of Life Sciences, University of Coimbra, 3004-517 Coimbra, Portugal. Phone: 351-239-855760. Fax: 351-239-855789. E-mail: pauloliv@ci.uc.pt.

\section{Funding Sources}

The present work was supported by Portuguese Foundation for Science and Technology through research grant PTDC/QUIQUI/101409/2008 (to P.J.O.) and a Ph.D. fellowship SFRH/ BD $/ 38067 / 2007$ (to T.L.S.).

\section{ACKNOWLEDGMENT}

We thank Cátia Diogo for excellent technical support.

\section{ABBREVIATIONS}

$\mathrm{ADP}$, adenosine diphosphate; ATP, adenosine triphosphate; $\mathrm{CA}$, caffeic acid; CsA, cyclosporin A; DMSO, dimethylsulfoxide; $\log D$, distribution coefficient; FA, ferulic acid; FCCP, carbonyl cyanide $p$ trifluoromethoxyphenylhydrazone; HC, hexyl caffeate; HCA, caffeoylhexylamide; HF, hexylferulate; HFA, feruloylhexylamide; MPT, mitochondrial permeability transition; $\log P$, partition coefficient; $\mathrm{RCR}$, respiratory control ratio; ROS, reactive oxygen species; TMRM, tetramethyl rhodamine methyl ester; $\mathrm{TPP}^{+}$, tetraphenylphosphonium cation.

\section{REFERENCES}

(1) Fresco, P., Borges, F., Diniz, C., and Marques, M. P. (2006) New insights on the anticancer properties of dietary polyphenols. Med. Res. Rev. 26, 747-766.

(2) Fresco, P., Borges, F., Marques, M. P., and Diniz, C. (2010) The anticancer properties of dietary polyphenols and its relation with apoptosis. Curr. Pharm. Des. 16, 114-134.

(3) Huang, W. Y., Cai, Y. Z., and Zhang, Y. (2010) Natural phenolic compounds from medicinal herbs and dietary plants: potential use for cancer prevention. Nutr. Cancer 62, 1-20.

(4) Lee, K. W., and Lee, H. J. (2006) The roles of polyphenols in cancer chemoprevention. BioFactors 26, 105-121.

(5) Czuba, Z., Krol, W., Scheller, S., and Shani, J. (1992) Effect of cinnamic and acrylic acids' derivatives on luminol-enhanced chemiluminescence of neutrophils. Z. Naturforsch., C: J. Biosci. 47, 753-756.

(6) Bravo, L. (1998) Polyphenols: chemistry, dietary sources, metabolism, and nutritional significance. Nutr. Rev. 56, 317-333.

(7) Kelloff, G. J. (2000) Perspectives on cancer chemoprevention research and drug development. Adv. Cancer Res. 78, 199-334.

(8) Serafim, T. L., Marques, M. P., Borges, F., and Oliveira, P. J. (2008) Mitochondria as a target for novel chemotherapeutic agents based on phenolic acids. J. Theor. Exp. Pharm. 1, 3-13.

(9) Fiuza, S. M., Gomes, C., Teixeira, L. J., Girao da Cruz, M. T., Cordeiro, M. N., Milhazes, N., Borges, F., and Marques, M. P. (2004) Phenolic acid derivatives with potential anticancer properties: a structure-activity relationship study. Part 1: methyl, propyl and octyl esters of caffeic and gallic acids. Bioorg. Med. Chem. 12, 3581-3589.

(10) Gomes, C. A., da Cruz, T. G., Andrade, J. L., Milhazes, N., Borges, F., and Marques, M. P. (2003) Anticancer activity of phenolic acids of natural or synthetic origin: a structure-activity study. J. Med. Chem. 46, 5395-5401.

(11) Esteves, M., Siquet, C., Gaspar, A., Rio, V., Sousa, J. B., Reis, S., Marques, M. P., and Borges, F. (2008) Antioxidant versus cytotoxic properties of hydroxycinnamic acid derivatives: a new paradigm in phenolic research. Arch. Pharm. (Weinheim) 341, 164-173.

(12) Marques, M. P. M., Borges, F., Sousa, J. B., Calheiros, R, Garrido, J., Gaspar, A., Antunes, F., Diniz, C., and Fresco, P. (2006) Cytotoxic and COX-2 inhibition properties of Hydroxycinnamic derivatives. Lett. Drug Design Discovery 3, 316-320.

(13) Gao, S., and Hu, M. (2010) Bioavailability challenges associated with development of anti-cancer phenolics. Mini. Rev. Med. Chem. 10, $550-567$.

(14) Crozier, A., Jaganath, I. B., and Clifford, M. N. (2009) Dietary phenolics: chemistry, bioavailability and effects on health. Nat. Prod. Rep. 26, 1001-1043.

(15) Roleira, F. M., Siquet, C., Orru, E., Garrido, E. M., Garrido, J., Milhazes, N., Podda, G., Paiva-Martins, F., Reis, S., Carvalho, R. A., Silva, E. J., and Borges, F. (2010) Lipophilic phenolic antioxidants: correlation between antioxidant profile, partition coefficients and redox properties. Bioorg. Med. Chem. 18, 5816-5825.

(16) Shaw, J. M., and Winge, D. R. (2009) Shaping the mitochondrion: mitochondrial biogenesis, dynamics and dysfunction. Conference on Mitochondrial Assembly and Dynamics in Health and Disease. EMBO Rep. 10, 1301-1305.

(17) Weinberg, F., and Chandel, N. S. (2009) Mitochondrial metabolism and cancer. Ann. N.Y. Acad. Sci. 1177, 66-73.

(18) Gogvadze, V., Orrenius, S., and Zhivotovsky, B. (2009) Mitochondria as targets for cancer chemotherapy. Semin. Cancer Biol. 19, $57-66$.

(19) Ralph, S. J., and Neuzil, J. (2009) Mitochondria as targets for cancer therapy. Mol. Nutr. Food. Res. 53, 9-28. 
(20) Pereira, C. V., Moreira, A. C., Pereira, S. P., Machado, N. G., Carvalho, F. S., Sardao, V. A., and Oliveira, P. J. (2009) Investigating drug-induced mitochondrial toxicity: a biosensor to increase drug safety? Curr. Drug Saf. 4, 34-54.

(21) Pereira, G. C., Branco, A. F., Matos, J. A., Pereira, S. L., Parke, D., Perkins, E. L., Serafim, T. L., Sardao, V. A., Santos, M. S., Moreno, A. J., Holy, J., and Oliveira, P. J. (2007) Mitochondrially targeted effects of berberine [Natural Yellow 18, 5,6-dihydro-9,10-dimethoxybenzo(g)1,3-benzodioxolo(5,6-a) quinolizinium] on K1735-M2 mouse melanoma cells: comparison with direct effects on isolated mitochondrial fractions. J. Pharmacol. Exp. Ther. 323, 636-649.

(22) Lin, Z. X., Hoult, J. R., and Raman, A. (1999) Sulphorhodamine $\mathrm{B}$ assay for measuring proliferation of a pigmented melanocyte cell line and its application to the evaluation of crude drugs used in the treatment of vitiligo. J. Ethnopharmacol. 66, 141-150.

(23) Serafim, T. L., Oliveira, P. J., Sardao, V.A., Perkins, E., Parke, D., and Holy, J. (2008) Different concentrations of berberine result in distinct cellular localization patterns and cell cycle effects in a melanoma cell line. Cancer Chemother. Pharmacol. 61, 1007-1018.

(24) Rolo, A. P., Oliveira, P. J., Moreno, A. J., and Palmeira, C. M. (2000) Bile acids affect liver mitochondrial bioenergetics: possible relevance for cholestasis therapy. Toxicol. Sci. 57, 177-185.

(25) Gornall, A. G., Bardawill, C. J., and David, M. M. (1949) Determination of serum proteins by means of the biuret reaction. J. Biol. Chem. 177, 751-766.

(26) Oliveira, P. J., Santos, D. J., and Moreno, A. J. (2000) Carvedilol inhibits the exogenous $\mathrm{NADH}$ dehydrogenase in rat heart mitochondria. Arch. Biochem. Biophys. 374, 279-285.

(27) Chance, B., Williams, G. R., and Hollunger, G. (1963) Inhibition of electron and energy transfer in mitochondria. III. Spectroscopic and respiratory effects of uncoupling agents. J. Biol. Chem. 238, 439-444.

(28) Oliveira, P. J., Coxito, P. M., Rolo, A. P., Santos, D. L., Palmeira, C. M., and Moreno, A. J. (2001) Inhibitory effect of carvedilol in the high-conductance state of the mitochondrial permeability transition pore. Eur. J. Pharmacol. 412, 231-237.

(29) Kamo, N., Muratsugu, M., Hongoh, R., and Kobatake, Y. (1979) Membrane potential of mitochondria measured with an electrode sensitive to tetraphenyl phosphonium and relationship between proton electrochemical potential and phosphorylation potential in steady state. J. Membr. Biol. 49, 105-121.

(30) Oliveira, P. J., Esteves, T., Rolo, A. P., Palmeira, C. M., and Moreno, A. J. (2004) Carvedilol inhibits the mitochondrial permeability transition by an antioxidant mechanism. Cardiovasc. Toxicol. 4, 11-20.

(31) Broekemeier, K. M., Dempsey, M. E., and Pfeiffer, D. R. (1989) Cyclosporin $\mathrm{A}$ is a potent inhibitor of the inner membrane permeability transition in liver mitochondria. J. Biol. Chem. 264, 7826-7830.

(32) Halestrap, A. P. (2009) What is the mitochondrial permeability transition pore? J Mol. Cell. Cardiol. 46, 821-831.

(33) Fedotcheva, N. I., Kazakov, R. E., Kondrashova, M. N., and Beloborodova, N. V. (2008) Toxic effects of microbial phenolic acids on the functions of mitochondria. Toxicol. Lett. 180, 182-188.

(34) Jung, B. I., Kim, M. S., Kim, H. A., Kim, D., Yang, J., Her, S., and Song, Y. S. (2010) Caffeic acid phenethyl ester, a component of beehive propolis, is a novel selective estrogen receptor modulator. Phytother. Res. 24, 295-300.

(35) Rajan, P., Vedernikova, I., Cos, P., Berghe, D. V., Augustyns, K., and Haemers, A. (2001) Synthesis and evaluation of caffeic acid amides as antioxidants. Bioorg. Med. Chem. Lett. 11, 215-217.

(36) Son, S., Lobkowsky, E. B., and Lewis, B. A. (2001) Caffeic acid phenethyl ester (CAPE): synthesis and X-ray crystallographic analysis. Chem. Pharm. Bull. (Tokyo) 49, 236-238.

(37) Nomura, E., Hosoda, A., Morishita, H., Murakami, A., Koshimizu, K., Ohigashi, H., and Taniguchi, H. (2002) Synthesis of novel polyphenols consisted of ferulic and gallic acids, and their inhibitory effects on phorbol ester-induced Epstein-Barr virus activation and superoxide generation. Bioorg. Med. Chem. 10, 1069-1075.

(38) Alao, J. P., Lam, E. W., Ali, S., Buluwela, L., Bordogna, W., Lockey, P., Varshochi, R., Stavropoulou, A. V., Coombes, R. C., and
Vigushin, D. M. (2004) Histone deacetylase inhibitor trichostatin A represses estrogen receptor alpha-dependent transcription and promotes proteasomal degradation of cyclin D1 in human breast carcinoma cell lines. Clin. Cancer Res. 10, 8094-8104.

(39) Peetla, C., Bhave, R., Vijayaraghavalu, S., Stine, A., Kooijman, E., and Labhasetwar, V. (2010) Drug resistance in breast cancer cells: biophysical characterization of and doxorubicin interactions with membrane lipids. Mol. Pharm. 7, 2334-2348.

(40) Doyle, L. A., and Ross, D. D. (2003) Multidrug resistance mediated by the breast cancer resistance protein BCRP (ABCG2). Oncogene 22, 7340-7358.

(41) Vaseva, A. V., and Moll, U. M. (2009) The mitochondrial p53 pathway. Biochim. Biophys. Acta 1787, 414-420.

(42) Sardao, V. A., Oliveira, P. J., Holy, J., Oliveira, C. R., and Wallace, K. B. (2009) Doxorubicin-induced mitochondrial dysfunction is secondary to nuclear p53 activation in $\mathrm{H} 9 \mathrm{c} 2$ cardiomyoblasts. Cancer Chemother. Pharmacol. 64, 811-827.

(43) Szliszka, E., Czuba, Z. P., Domino, M., Mazur, B., Zydowicz, G., and Krol, W. (2009) Ethanolic extract of propolis (EEP) enhances the apoptosis-inducing potential of TRAIL in cancer cells. Molecules $14,738-754$.

(44) Mayevsky, A. (2009) Mitochondrial function and energy metabolism in cancer cells: past overview and future perspectives. Mitochondrion 9, 165-179.

(45) Gogvadze, V., Zhivotovsky, B., and Orrenius, S. (2010) The Warburg effect and mitochondrial stability in cancer cells. Mol. Aspects Med. 31, 60-74.

(46) Sardao, V. A., Pereira, S. L., and Oliveira, P. J. (2008) Druginduced mitochondrial dysfunction in cardiac and skeletal muscle injury. Expert Opin. Drug Saf. 7, 129-146.

(47) Huang, D. W., Shen, S. C., and Wu, J. S. (2009) Effects of caffeic acid and cinnamic acid on glucose uptake in insulin-resistant mouse hepatocytes. J. Agric. Food Chem. 57, 7687-7692.

(48) Manach, C., Scalbert, A., Morand, C., Remesy, C., and Jimenez, L. (2004) Polyphenols: food sources and bioavailability. Am. J. Clin. Nutr. 79, 727-747.

(49) Wang, S. J., Zhang, Z. Q., Zhao, Y. H., Ruan, J. X., and Li, J. L. (2006) Simultaneous quantification of chlorogenic acid and caffeic acid in rat plasma after an intravenous administration of mailuoning injection using liquid chromatography/mass spectrometry. Rapid Commun. Mass Spectrom. 20, 2303-2308.

(50) Coimbra, M., Isacchi, B., van Bloois, L., Torano, J. S., Ket, A., Wu, X., Broere, F., Metselaar, J. M., Rijcken, C. J., Storm, G., Bilia, R., and Schiffelers, R. M. (2011) Improving solubility and chemical stability of natural compounds for medicinal use by incorporation into liposomes. Int. J. Pharm. [online early access], DOI: 10.1016/j.ijpharm. 2011.01.056 